\title{
Life cycle energy and material flow implications of gypsum plasterboard recycling in the European Union
}

\author{
Ana Jiménez Rivero ${ }^{\mathrm{a} *}$, Roger Sathre ${ }^{\mathrm{b}}$, Justo García Navarro ${ }^{\mathrm{a}}$ \\ ${ }^{a}$ Research Group Sustainability in Construction and Industry giSCI - UPM, Universidad Politécnica de Madrid. Ciudad \\ Universitaria s/n, 28040 Madrid, Spain. \\ ${ }^{\mathrm{b}}$ Energy Technologies Area, Lawrence Berkeley National Laboratory, Berkeley California 94720, USA \\ * Corresponding author. Tel.: +34 9133658 65; fax: +34 913363688 \\ E-mail address: ana.jimenez@upm.es
}

\begin{abstract}
Turning waste into a resource is a way to increase resource use efficiency and close the material loop of a circular economy. Gypsum plasterboard is well suited for this, because the raw material calcium sulphate dihydrate $\left(\mathrm{CaSO}_{4} \cdot 2 \mathrm{H}_{2} \mathrm{O}\right)$ can repeatedly change its properties through a reversible hydration reaction. The waste hierarchy is applied when plasterboard is recycled instead of landfilled, which contributes to the European 2020 target of $70 \%$ recovery of construction and demolition (C\&D) waste, as defined in the Directive 2008/98/EC on Waste. This paper evaluates the energy and climate impacts of different levels of plasterboard recycling. First we formulate a life cycle model of gypsum mass flows in the European Union (EU-27) in the reference year 2013. This model constitutes the basis of the quantitative scenario analysis. Secondly we assess the material flows, energy use and greenhouse gas (GHG) emissions in different recycling scenarios. We compare the current situation ("2013 base case") to two scenarios: a worst case scenario of $0 \%$ recycled gypsum ("Zero recycling case"), and a best case scenario of zero gypsum waste sent to landfill, corresponding to $18.7 \%$ recycled gypsum in new plasterboard ("High recycling case"). We find no significant variation between scenarios in terms of life cycle energy use, as lower impacts from gypsum mining, transport of natural gypsum and final disposal in the best case scenario are balanced by the energy for the transport of plasterboard waste and recycled gypsum and for material pre-processing during manufacturing. In contrast, life cycle GHG emissions are lower as recycling increases, largely driven by the degradation of plasterboard lining paper in landfills.
\end{abstract}

Keywords: gypsum plasterboard; European Union; material flow analysis; life cycle assessment (LCA); primary energy; GHG emissions.

\section{Highlights}

- Gypsum is fully recyclable, changing form based on a reversible hydration reaction.

- A life cycle model is developed of gypsum plasterboard in the EU-27.

- Relations between gypsum recycling, energy use and GHG emissions are established.

- Gypsum plasterboard recycling can contribute to achieving EU resource-efficiency targets. 


\section{Introduction}

Working towards greater resource efficiency in the construction sector is essential for addressing global issues such as mitigating climate change and moving to a more circular economy, and is essential to achieving the resource efficiency agenda established under the Europe 2020 Strategy for smart, sustainable and inclusive growth (Antink, Garrigan, Bonetti, \& Westaway, 2014; European Commission, 2014a). A circular economy system keeps the added value in products for as long as possible and reduces waste. This strategy of turning waste into a resource is an essential part of increasing resource efficiency and "closing the loop" in a circular economy (European Commission, 2014b). Closed-loop supply chain management entails the design, control, and operation of a system to maximize value creation over the entire life cycle of a product with dynamic recovery of value from different types and volumes of returns over time (Govindan, Soleimani, \& Kannan, 2014). It implies forward and reverse supply chains operating simultaneously, and closed-loop recycling as a necessary link for its success.

Gypsum is a versatile construction material that can effectively close the material loop, being fully and eternally recyclable. Unfortunately, a large proportion of gypsum waste is currently being landfilled worldwide, including building plaster, gypsum blocks and plasterboard waste (the latter being the most common recyclable gypsum waste generated in Europe). However, the processing of gypsum waste into high quality recycled gypsum is possible, already occurring in different regions of Belgium, Finland, France, Denmark, Sweden, the Netherlands and the United Kingdom, in which recycling systems are now operating and supplying plasterboard manufacturers. Moreover, all over Europe efforts are being made to increase the recycling rate of this material, boosted by the development of the Life+ GtoG project, which from January 2013 has been working to transform the gypsum waste market, with the aim of achieving higher gypsum recycling rates in Europe (GtoG Project, 2013). This approach contributes to mitigating primary resource depletion, contributing at the same time to minimizing construction and demolition (C\&D) waste streams sent to landfills.

Knowledge of the quantities of waste streams generated constitutes an essential step in the development of an appropriate scheme for their management (Kourmpanis et al., 2008). Material flow analysis (MFA) is an analytical approach to quantifying the system-wide flows and stocks of materials associated with a defined product. Life-cycle assessment (LCA) is the compilation and evaluation of the inputs, outputs and potential environmental impacts of a product system throughout its life cycle (International Standard, 2006a). Together, these approaches provide the means to evaluate the environmental implications of gypsum plasterboard recycling.

Consequently, the formulation of a life cycle model associated with gypsum plasterboard material flows in the European Union, in the reference year 2013, constitutes the basis of this investigation. It enables establishing the relations between gypsum recycling, energy use and GHG emissions, in a life cycle perspective. Scenario-based modelling has been conducted for this purpose, evaluating the impact of different levels of recycled gypsum reincorporated in the manufacturing process. To our knowledge, this analysis is the first to comprehensively quantify the system-wide life cycle energy and mass flows associated with gypsum plasterboard in EU-27, and to model their changes under varying levels of plasterboard recycling.

\section{The life cycle of gypsum plasterboard}

The life cycle of gypsum plasterboard typically begins with the extraction and processing of raw materials, continues with the manufacture and use of the plasterboard, and then reaches end-of-life (EoL) that involves either landfilling, recycling or other forms of recovery (Fig. 1). These life cycle processes are described in the following sub-sections 2.1-2.4. 


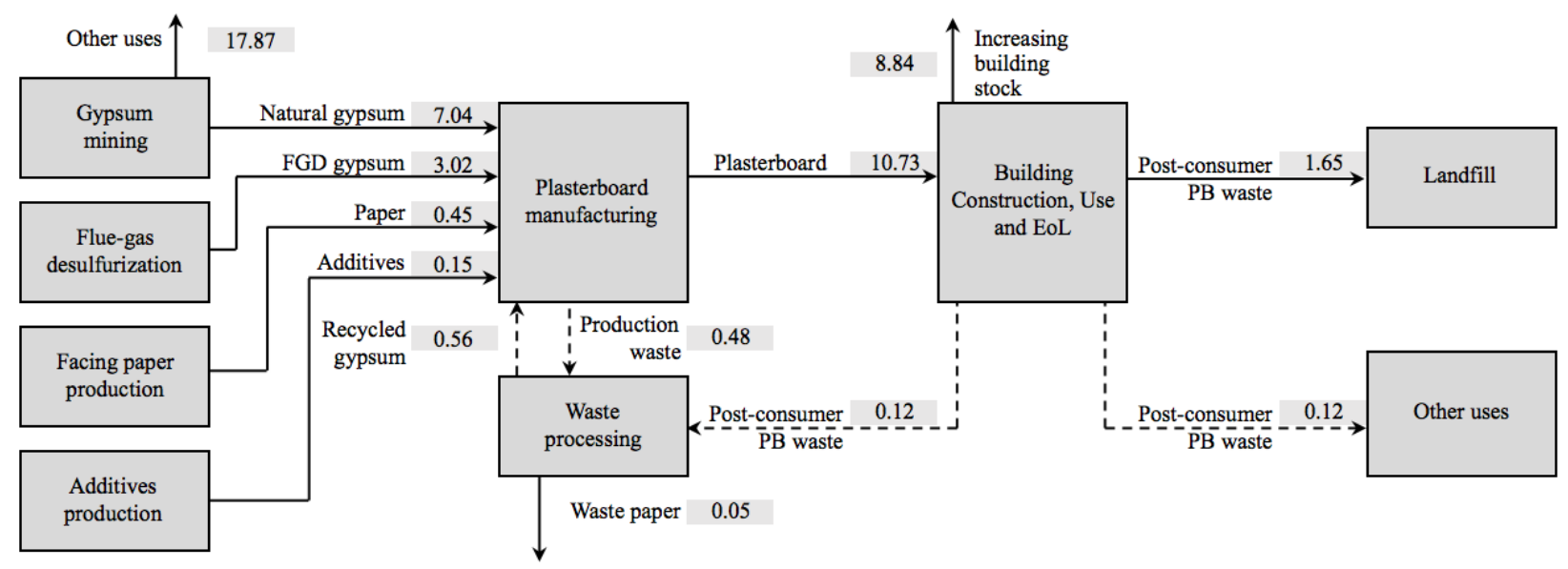

Fig. 1. Life cycle system-wide mass flows associated with gypsum plasterboard. The numbers indicate million tons of material flows in the EU-27 in the reference year 2013 and is the basis of scenario "2013 base case" described in Section 3. PB: plasterboard; EoL: End-of-Life. Reverse logistics shown with dashed line.

\subsection{Supply of gypsum and other inputs}

Sources of gypsum for plasterboard production include gypsum mining, flue gas desulfurization (FGD) gypsum, and recycled products. Other required plasterboard inputs include paper and additives.

- Natural gypsum

Natural gypsum is a mineral composed of calcium sulphate dihydrate $\left(\mathrm{CaSO}_{4} \cdot 2 \mathrm{H}_{2} \mathrm{O}\right)$. Data on gypsum mine production are provided by several different sources (Eurostat - Prodcom, 2013b; Roskill, 2014; U.S. Geological Survey - USGS, 2013). The authors consider the annual publication Roskill Report (Roskill, 2014) to be the most authoritative estimate, as it is based on data from the other two references (U.S. Geological Survey - USGS, 2013) as well as company reports and trade press. According to this report, 24.91 Mt of natural gypsum were mined in the EU-27 in 2013. Globally, 139.38 Mt of gypsum were mined in 2013. In addition to plasterboard production, gypsum is also used in other plaster products, in cement manufacture, and for agricultural applications. Gypsum mining involves drilling and blasting the rock, after which it is loaded onto trucks using front-end loaders and mechanical shovels (Venta, 1997). Gypsum extraction processes typically use diesel fuel and electric power. World resources of natural gypsum are considered to be large, and are expected to be sufficient to meet demand well into the future (Roskill, 2014). Although there is no global shortage of natural gypsum, mining can cause impacts in terms of land occupation, energy use and potential loss in biodiversity (European Commission DG Environment, 2010).

The gypsum industry uses synthetic gypsum that is a by-product of industrial processes used to reduce sulphur emissions from coal-fired power plants. Flue-gas desulphurization (FGD) systems consist of wet scrubbers that remove sulphur dioxide $\left(\mathrm{SO}_{2}\right)$ through the reaction with an alkaline material such as lime. This process is shown in Equation 1, where lime slurry $\left(\mathrm{Ca}(\mathrm{OH})_{2}\right)$ is used to remove the $\mathrm{SO}_{2}$ from the flue gas, creating calcium sulphite $\left(\mathrm{CaSO}_{3}\right)$ and water.

$$
\mathrm{Ca}(\mathrm{OH})_{2(\text { solid })}+\mathrm{SO}_{2(\text { gas })} \rightarrow \mathrm{CaSO}_{3 \text { (solid) }}+\mathrm{H}_{2} \mathrm{O}_{(\text {liquid })}
$$

For this by-product to be used as raw material for plasterboard production, it must be further oxidized (Equation 2). Additional energy is required for this forced oxidation to produce calcium sulphate dihydrate 
estimated by (WRAP and Environmental Resources Management Ltd (ERM), 2008) at $1.4 \mathrm{MJ}$ of coal combustion per kg of FGD gypsum produced.

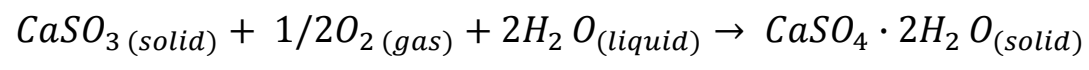

FGD gypsum is produced in several EU countries, but is concentrated in Germany where 6 Mt of the estimated total EU production of $8 \mathrm{Mt}$ was produced in 2013 (Roskill, 2014). Of this total production, and based on the latest published ECOBA statistics (ECOBA - European Coal Combustion Products Association, 2010), 50.6\% was used for plasterboard manufacturing in the EU-15 in 2010. This is an average figure; in some EU countries such as France, Spain and Italy, the use of FGD gypsum is limited or non-existent, while the use is higher in others such as Belgium, Germany and Scandinavian countries. There are currently EU and national political debates about sustainable energy, the EU commitment to reduce $\mathrm{CO}_{2}$ emissions, secure energy supply including the need to balance the energy mix, the growing need to use renewable energy sources and the development of new efficient technologies for power generation. Together, these factors are expected to reduce coal use and thus the production of FGD gypsum within the coming decades, particularly in Germany and other western EU member states.

Other sources of synthetic gypsum, such as phosphogypsum, fluorogypsum and titanogypsum, have not been considered here as they are usually consumed by other markets (such as cement manufacture) and not used in significant amounts in plasterboard manufacturing in the EU-27 (Roskill, 2014).

- Recycled gypsum

Recycled gypsum is the result of controlled processing of waste plasterboard to separate the gypsum, paper lining, and any impurities, such that it can be used in lieu of natural or synthetic gypsum. The recycled gypsum can be either pre-consumer or post-consumer. As a general rule, pre-consumer gypsum waste is cleaner than post-consumer gypsum waste. Pre-consumer recycled gypsum is material diverted from the waste stream during a manufacturing process (International Standard, 1999). Post-consumer recycled gypsum usually comes from recyclers (Construction Recycling Initiative (CRI) - National Capital Region, 2010), mainly from C\&D gypsum waste. Recycled gypsum is usually in the form of a fine or sandy powder, or a small-aggregate type material (WRAP and Environmental Resources Management Ltd (ERM), 2008).

Plasterboard has been identified as one of the major components contributing to the total potential recycled content of a construction project, in terms of recycled value (Emery, Smith, Gaterell, Sammons, \& Moon, 2007). Following the need to reduce the volume of $C \& D$ waste sent to landfill and to increase the efficiency of using resources, the use of recycled gypsum is expected to grow in the coming years.

- Paper and additives

Two other inputs to plasterboard production are required. Facing paper is applied to both sides of the gypsum plaster core, providing most of the tensile strength to the plasterboard. Recycled paper is typically used as plasterboard lining in the EU-27, according to ELCD process data (European Commission Joint Research Centre - European reference Life-Cycle Database, 2007). Furthermore, small amounts of additives such as starch, lignin, perlite, vermiculite, soap foam, retarders, shredded paper, and accelerators are also used.

\subsection{Plasterboard manufacturing}

During plasterboard manufacturing, the process inputs including natural, FGD and recycled gypsum, paper and additives are combined to form the gypsum plasterboard product. Regardless of the source of the gypsum raw material, the calcium sulphate dihydrate $\left(\mathrm{CaSO}_{4} \cdot 2 \mathrm{H}_{2} \mathrm{O}\right)$ is first heated (calcined) and partially 
dehydrated to form calcium sulphate hemihydrate $\left(\mathrm{CaSO}_{4} \cdot 1 / 2 \mathrm{H}_{2} \mathrm{O}\right)$, called stucco in the industry and also popularly known as "Plaster of Paris" (Equation 3).

$$
\mathrm{CaSO}_{4} \cdot 2 \mathrm{H}_{2} \mathrm{O} \rightarrow^{(\text {heat })} \mathrm{CaSO}_{4} \cdot 1 / 2 \mathrm{H}_{2} \mathrm{O}+11 / 2 \mathrm{H}_{2} \mathrm{O}
$$

The process of calcining (also known as calcination) is commonly associated with the heat-driven removal of $\mathrm{CO}_{2}$ from limestone to produce lime, but more generally refers to the thermal treatment of solid materials and need not involve reaction emissions of $\mathrm{CO}_{2}$. Calcination of gypsum raw material results in partial dehydration of the mineral, with the only reaction emission being water vapor.

Next, measured quantities of calcium sulphate hemihydrate, additives and water are mixed, creating a gypsum slurry. This slurry is spread in a uniform thickness onto a layer of facing paper, and then covered by another layer of facing paper. The gypsum then re-hydrates to form hard calcium sulphate dihydrate (Equation 4).

$$
\mathrm{CaSO}_{4} \cdot 1 / 2 \mathrm{H}_{2} \mathrm{O}+11 / 2 \mathrm{H}_{2} \mathrm{O} \rightarrow \mathrm{CaSO}_{4} \cdot 2 \mathrm{H}_{2} \mathrm{O}
$$

The gypsum core of the manufactured plasterboard takes around four to five minutes to harden (Roskill, 2014). When the hydration is completed, the gypsum has been chemically restored to its rock-like state as found in nature (dihydrate), forming the gypsum core of the plasterboard, encased in paper. The resulting boards are then cut to the desired length and sent to a drying kiln. Excess water is driven off in drying kiln (EPA's Waste Reduction Model (WARM), 2014; Roskill, 2014; Venta, 1997). The finished sheets are then prepared for shipment.

GHG emissions and energy consumption in plasterboard manufacturing mainly come from:

- Manufacturing of paper (paper making process) and additives.

- Pre-processing including size reduction (crushing and grinding) and pre-drying operations of gypsum raw material before calcination.

- Gypsum calcination (calcium sulphate dihydrate to stucco), also known as stucco production (WRAP and Environmental Resources Management Ltd (ERM), 2008), which is a reversible process, making gypsum an indefinitely recyclable material.

- Plasterboard production, which involves the mixing of the stucco slurry, paper feeding, setting, cutting and drying of plasterboard in drying kilns.

Previous studies in the US (EPA's Waste Reduction Model (WARM), 2014) estimate the following energy use breakdown within the plasterboard production stages: $13 \%$ for raw material obtention, $3 \%$ for raw material transportation, and $85 \%$ for plasterboard manufacturing. Due to the nature of the chemical process and materials used, there are no non-energy process emissions of GHGs from plasterboard manufacturing (EPA's Waste Reduction Model (WARM), 2014)

\subsection{Plasterboard use in buildings: construction, use and end-of-life (EoL)}

Gypsum plasterboard as a material provides good levels of acoustic and thermal insulation, and as a system, the cavities behind the main face can accommodate further insulation. This product also offers a high level of fire protection, due to gypsum's water content and non-combustible nature (European Commission DG Environment, 2010). It is used for partitions, ceilings and lining of walls. Apart from its use in new construction works, it is extended in refurbishment solutions for thermally insulating existing buildings, being part of improved wall insulation solutions (Dodoo, Gustavsson, \& Sathre, 2010), lowered ceilings, creating air voids below old ceilings or supporting thermal insulation (Bojić, Djordjević, Stefanović, Miletić, \& Cvetković, 2012). 
By using plasterboard walls, C\&D waste generation per square meter of build surface can be reduced $16 \%$ by weight and $3 \%$ by volume, compared to using traditional brick partitions (Villoria Sáez, del Río Merino, Porras-Amores, \& San-Antonio González, 2014). Plasterboard use involves less involvement of labour, short installation time and smooth wall surface quality (Tam, Fung, Sing, \& Ogunlana, 2014). A progressive change in building procedures, substituting internal brick walls with plasterboard products, has being reported even in countries where brick walls have been traditionally used (Herrero, Escavy, \& Bustillo, 2013).

217 Plasterboard is widely used in most of the European countries, and those with the strongest plasterboard use are usually the lowest consumers of other plaster products (mainly used in traditional masonry construction). A well-established plasterboard market currently exists in Germany, France and the United Kingdom, covering more than 53\% of the European market volume (European Commission Joint Research Centre European reference Life-Cycle Database, 2007). The highest consumption of plasterboard (in $\mathrm{m}^{2}$ per capita) is found in Denmark, France, Ireland, Austria, Finland, Sweden and the United Kingdom (Gypsum to Gypsum project LIFE11 ENV/BE/001039, 2013).

\subsection{End-of-life options for gypsum plasterboard}

Pre-consumer gypsum waste generated during the manufacturing process is usually known as production waste, and includes out-of-specification boards and boards damaged during packaging. The recycling of this production waste is commonly done as part of corporate waste avoidance policy.

Once the material leaves the manufacturing facility, damaged or unused plasterboard from distributors and retailers and fit-out waste from installation (offcuts, damaged or unused on site) becomes construction waste. Recyclable demolition plasterboard waste is usually strip-out waste resulting from deconstruction or selective demolition works, which involves dismantling, segregation and storage of gypsum waste. Effective deconstruction operations are crucial to maximizing the recyclable gypsum waste stream. Manual dismantling and segregation operations of plasterboard waste are assumed to be the common practice during deconstruction in our scenarios. The use of mechanical equipment (e.g. sorting grabs) are only observed on a case-by-case basis, particularly when a high amount of gypsum waste generation is foreseen (Gypsum to Gypsum project LIFE11 ENV/BE/001039, 2015).

Detailed gypsum waste generation and disposal statistics are unavailable at the European or national levels. The authors have found only one estimate, that about $4 \mathrm{Mt}$ of gypsum waste are generated in Europe annually (only considering construction waste), of which between 25 to $30 \%$ comes from plasterboard (European Commission, 2011). Buildings currently being deconstructed in Europe contain other plaster products but relatively little plasterboard, as plasterboard was not commonly used when these buildings were constructed, e.g. 50 - 60 years ago. Plasterboard content in C\&D waste is expected to increase in the future, as buildings constructed more recently reach the end of their service lives and are deconstructed.

The level of landfilling of C\&D waste varies greatly across the EU, from 10\% to 90\% (European Commission, 2011). Countries such as Cyprus, Czech Republic, Greece, Hungary, Poland, Portugal and Spain currently experience high landfilling rates. However, estimates are not available for all EU countries, and high variability is observed between different data sources, likely due to the lack of standardized control and reporting mechanisms.

High concentrations of hydrogen sulphide $\left(\mathrm{H}_{2} \mathrm{~S}\right)$ at $\mathrm{C} \& \mathrm{D}$ debris landfills are attributed to $\mathrm{H}_{2} \mathrm{~S}$ generation from the disposal of gypsum plasterboard. Council Decision 2003/33/EC established that "Non-hazardous gypsum-based material should be disposed of only in landfills for non-hazardous waste in cells where no biodegradable waste is accepted" (The Council of the European Union, 2003). This is because gypsum waste is a high-sulphate waste, and if it is deposited in normal cells in non-hazardous landfills, its sulphate can break down into, amongst other substances, hydrogen sulphide $\left(\mathrm{H}_{2} \mathrm{~S}\right)$. This is a colourless, flammable, 
extremely hazardous gas associated with environmental and health effects, that even in low concentrations creates odour problems (OSHA Occupational Safety and Health Administration. US Department of Labor, 2005). The emission rate of $\mathrm{H}_{2} \mathrm{~S}$ is variable and depends on different factors such as soil moisture, $\mathrm{H}_{2} \mathrm{~S}$ concentration and temperature (Xu \& Townsend, 2014). In order to comply with this Council Decision, plasterboard or other gypsum waste should be disposed of in monocell landfills, meaning the disposal of plasterboard in separate landfill cells for high sulphate materials. However, its implementation is not always upheld, and thus gypsum waste is, in many cases, landfilled under improper conditions (European Commission, 2011).

Methane $\left(\mathrm{CH}_{4}\right)$ and carbon dioxide $\left(\mathrm{CO}_{2}\right)$ emissions are also generated when plasterboard is landfilled, formed during the degradation of the paper content. Methane produced in monocell landfills is released at a low rate, and is likely to undergo oxidation to $\mathrm{CO}_{2}$ in the surface layers of the site before being released to the atmosphere. In mixed waste landfills, however, methane from the degradation of plasterboard facing paper is likely to be released along with other landfill gases (WRAP and Environmental Resources Management Ltd (ERM), 2008). Some of this gas may be collected and either flared or used for energy, whereas the remainder will escape to the atmosphere as fugitive methane emissions.

Plasterboard waste is currently processed by dedicated gypsum recyclers, which usually receive gypsum waste from transfer stations, waste management companies, waste sorting facilities, or directly from jobsites, in conformance with relevant acceptance criteria. Several mechanical steps, such as grinding and sieving, take place for processing the gypsum waste into recycled gypsum. Plasterboard waste may also be used for other applications. For example, the agricultural use of gypsum as soil treatment is widespread in countries such as the UK. Cement production, manufacture of other construction products, soil stabilization and binding are some of the documented open-loop recycling practices (WRAP \& BSI, 2013). In Europe, gypsum recyclers operate in France, Belgium, the Netherlands, Luxembourg, Finland, the UK, Denmark, and Sweden. The amount processed is considered confidential and thus not reported by the gypsum recyclers.

Most of the EU countries are currently facing challenges in the management of gypsum waste, which is variable depending on each national context. For example, the emergence of gypsum recycling facilities is only expected to occur under certain conditions related to policy effectiveness and control. An important factor is the competitiveness of the recycling route, mainly determined by the cost of landfill disposal or a landfill ban. On the other hand, even when a market for recycled gypsum exists in a region, non-recyclable gypsum waste can be generated when demolition rather than deconstruction processes are used, which rely on different parameters such as manpower, cost, space and environmental focus of the waste owner. Nonrecyclable gypsum waste does not comply with gypsum recyclers' acceptance criteria that usually limit impurities $\leq 2 \%$ and wet gypsum $\leq 10 \%$ (Gypsum to Gypsum project LIFE11 ENV/BE/001039, 2015), Moreover, the difficulty of separating gypsum waste from a mixed waste stream (e.g. when the gypsum waste is not source segregated) increases the rate of landfilling. Furthermore, while alternative destinations that are lower in the waste hierarchy (e.g. backfilling) can limit or even disable closed-loop gypsum recycling, a reduced availability of natural and/or FGD gypsum might encourage the recycling of gypsum.

\section{Scenario projections of plasterboard recycling}

We begin by developing a life cycle model of gypsum plasterboard mass flows (Fig. 1), which describes all significant material streams associated with the life cycle of gypsum plasterboard consumed in the EU-27 in the reference year 2013. System boundaries include the material supply, manufacturing, installation and EoL stages. These processes are detailed in Table 1. Based on this model, we quantify the known flows of selected materials: natural gypsum and new plasterboard. We then apply principles of mass balance to 
determine flows of other materials, e.g. FGD gypsum, facing paper, waste plasterboard, and recycled gypsum.

303 Table 1. Life cycle stages of gypsum plasterboard, and processes within each stage.

\begin{tabular}{|c|c|}
\hline Stage & Process \\
\hline $\begin{array}{l}\text { Raw material supply, including processing of } \\
\text { secondary material input }\end{array}$ & $\begin{array}{l}\text { Gypsum mining } \\
\text { FGD gypsum } \\
\text { Paper } \\
\text { Additives } \\
\text { Waste processing (Production waste) } \\
\text { Total raw material supply }\end{array}$ \\
\hline $\begin{array}{l}\text { Transport of raw material and secondary material to the } \\
\text { manufacturer }\end{array}$ & $\begin{array}{l}\text { Transport natural gypsum } \\
\text { Transport FGD } \\
\text { Transport recycled gypsum } \\
\text { Transport paper } \\
\text { Transport additives } \\
\text { Total transport of raw and secondary materials }\end{array}$ \\
\hline Manufacture of plasterboard an all upstream processes & $\begin{array}{l}\text { Plasterboard manufacturing (Pre-processing) } \\
\text { Plasterboard manufacturing (Calcination, production) } \\
\text { Total plasterboard manufacturing }\end{array}$ \\
\hline Transport of plasterboard to the building site & Transport of plasterboard to the jobsite \\
\hline Plasterboard installation and/or deconstruction & Building Construction, Use and EoL \\
\hline Transport of the post-consumer plasterboard waste to waste processing & $\begin{array}{l}\text { Transport of post-consumer PB waste to waste } \\
\text { processing }\end{array}$ \\
\hline Waste processing of post-consumer plasterboard waste & Waste processing \\
\hline Final disposal of plasterboard & $\begin{array}{l}\text { Transport of post-consumer PB waste to landfill } \\
\text { Operation of landfill site } \\
\text { Biogenic emissions from landfill } \\
\text { Total final disposal }\end{array}$ \\
\hline
\end{tabular}

We conduct scenario-based modelling to evaluate the GHG emissions and primary energy implications of different levels of plasterboard recycling in EU-27. Our analysis is based on the mass flows associated with plasterboard installed in the reference year 2013. We then conduct quantitative scenario analysis to determine how system-wide material flows, energy use and GHG emissions would be affected by increased or decreased levels of recycled gypsum content in new plasterboard production. We compare the actual situation in 2013 that we term "2013 base case" (5\% recycled gypsum content of new plasterboard) with two alternative scenarios: "Zero recycling case" (0\% recycled gypsum) and "High recycling case" (18.7\% recycled gypsum reincorporated, corresponding to zero post-consumer plasterboard waste sent to landfill). We study how variations of selected parameters would affect the environmental impacts associated with gypsum plasterboard over its life cycle. Both the 2013 base case and high recycling case consider an input of $4 \%$ of pre-consumer recycled gypsum, as sources estimate that 3-5\% of production is lost as waste (Roskill, 2014). It should be noted that we devise alternative scenarios in order to enable comparative assessment of the 2013 base case against two extreme recycling rates: $0 \%$ and $18.7 \%$. The zero recycling case would be achievable under the worst of circumstances, although pre-consumer gypsum waste is commonly recycled. In contrast, the high recycling case would require $100 \%$ material recovery which is quite optimistic, thus represents an asymptote to be targeted. Although highly effective deconstruction techniques exist, they currently do not result in total gypsum waste segregation. 
Life cycle inventory (LCI) data for the analysis is taken from published literature and LCI databases. Data was selected from a variety of sources in order to meet ISO data quality requirements (International Standard, 2006b).

\subsection{Material flows}

Based on 5 European references of normal/standard plasterboard (Table 2), we formulate the statistical average of paper and additives contained in the plasterboard produced in the EU-27 (Table 3). For the case of Environmental Product Declarations (EPDs), only those available, reporting complete data for standard plasterboard and verified by an independent third party have been taken into account. We estimate the FGD gypsum reference proportion $(26.9 \%)$ in plasterboard by assuming $35.9 \%$ of recovered content in plasterboard (European Commission Joint Research Centre - European reference Life-Cycle Database, 2007), which includes recovered paper (4.0\%), recycled (5.0\%) and FGD gypsum. We term this the "Reference plasterboard". It is important to note that the proportion of each type of gypsum, paper and additives may vary by country and/or by manufacturer. The Technical Report of Life Cycle Assessment of Plasterboard (WRAP and Environmental Resources Management Ltd (ERM), 2008) is the only available European reference currently providing detailed data of the EoL stage (modules C1 - C4 according to EN 15804). Natural, FGD and recycled gypsum have been considered the main feedstock material of the Reference plasterboard.

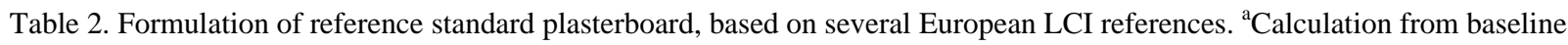
scenario mass flows

\begin{tabular}{|c|c|c|c|c|c|c|c|c|}
\hline \multirow[b]{2}{*}{ Reference } & \multirow[b]{2}{*}{ Region } & \multirow[b]{2}{*}{$\begin{array}{l}\text { Thickness } \\
(\mathrm{mm})\end{array}$} & \multirow[b]{2}{*}{$\begin{array}{l}\text { Density } \\
\left(\mathrm{kg} / \mathrm{m}^{2}\right)\end{array}$} & \multicolumn{5}{|c|}{ Contents in final product ( $\%$ by weight) } \\
\hline & & & & $\begin{array}{l}\text { Natural } \\
\text { gypsum }\end{array}$ & $\begin{array}{l}\text { Synthetic } \\
\text { gypsum }\end{array}$ & $\begin{array}{l}\text { Recycled } \\
\text { (pre+post } \\
\text { consumer) }\end{array}$ & $\begin{array}{l}\text { Paper } \\
\text { liner }\end{array}$ & Additives \\
\hline Bjorklund and Tillman, 1997 & $\mathrm{SE}$ & 13.0 & 9.0 & 47.3 & 47.3 & - & 4.9 & 0.5 \\
\hline WRAP, $2008^{a}$ & GB & 12.5 & - & 33.6 & 50.8 & 9.9 & 4.2 & 1.5 \\
\hline ELCD database 2.0, 2007 & EU-27 & 12.5 & 10.0 & - & & 35.9 & & - \\
\hline EPD System, 2013 & GB & 12.5 & 8.4 & 0.0 & & .5 & 3.0 & 2.5 \\
\hline EPD System, 2013 & SE & 12.5 & 9.0 & 45.8 & 45 & .7 & 3.8 & 0.7 \\
\hline
\end{tabular}

Table 3. Composition, by weight percentage, of the considered Reference plasterboard, based on the statistical average of total gypsum, paper and additives in plasterboard produced in the EU-27. Recovered content includes FGD gypsum, recycled gypsum and recycled paper.

\begin{tabular}{lr}
\hline Raw materials in Plasterboard & Reference PB \\
\hline Total gypsum & $94.7 \%$ \\
Natural gypsum & $62.8 \%$ \\
FGD gypsum & $26.9 \%$ \\
Recycled gypsum & $5.0 \%$ \\
Pre-consumer & $4.0 \%$ \\
Post-consumer & $1.0 \%$ \\
Facing paper & $4.0 \%$ \\
Additives & $1.3 \%$ \\
\hline Total recovered content & $35.9 \%$
\end{tabular}


We estimate the amount of plasterboard consumed in the EU-27 in 2013, by analysing statistics on the production of manufactured goods. Figures in the database are provided in $\mathrm{m}^{2}$ (Eurostat - Prodcom, 2013a). The four digits 2362 identify the plasterboard industry, according to the classification of the producing enterprise given by the Statistical Classification of Economic Activities in the European Community (NACE). The code 23621050 refers to boards, sheets, panels, tiles and similar articles of plaster or of compositions based on plaster, faced or reinforced with paper or paperboard only (excluding articles agglomerated with plaster, ornamented). The "Apparent consumption" has been taken as the indicator that reflects the proportion of installed plasterboard, by adding the imports quantity to the production quantity, and subtracting exports (Williams, 2008), based on data in the Prodcom list (NACE Rev.2), Sold production, exports and imports. It is therefore estimated that $1,073,464,249 \mathrm{~m}^{2}$ of plasterboard were consumed in the EU-27 in 2013. This equals $10.73 \mathrm{Mt}$ of weight material, by assuming $10 \mathrm{~kg} / \mathrm{m}^{2}$ as the standard plasterboard density, as considered in the EU process data set, available in the EU ELCD database and representative of the EU-27 region for the period 2007-2014.

Plasterboard installation, dismantling or demolition generates post-consumer plasterboard waste. The paucity of reliable references studying its generation in Europe is a major challenge we faced in modelling the EoL mass balances. Our estimates are based on the amount of plasterboard waste generated in 8 European member states (Belgium, Denmark, Greece, Spain, France, the Netherlands, Poland the United Kingdom) assessed in the framework of the GtoG project, equalling 1.15 Mt (Gypsum to Gypsum project LIFE11 $\mathrm{ENV} / \mathrm{BE} / 001039,2013)$. In these 8 countries, the total C\&D waste generated amounted to around 499 million tonnes in 2012, the latest update of the Eurostat database (Eurostat, 2012). This means an estimated rate of post-consumer plasterboard waste of $0.23 \%$ of the total $C \& D$ waste in the EU-27, equivalent to 1.9 million tonnes, whose final route is either recycling, landfill disposal or other uses including re-use, recovery and open loop recycling. In all scenarios, we assume that the same amount following the recycling route in the 2013 base case is sent to other uses. The remaining waste is considered to be deposited in landfill.

On this basis, we determine the amount of post-consumer plasterboard waste following the recycling route, as the post-consumer recycled gypsum reincorporation rate into the manufacturing process is a known value in our model (i.e. $1 \%$ by weight of new plasterboard in the 2013 base case). We assume that, after processing of the plasterboard waste, $7.5 \%$ by weight will result in waste paper (a mix of lining paper with gypsum residues), which is sent to the paper industry for recycling, and therefore considered outside the boundaries of this investigation. The resulting amount of post and pre-consumer recycled gypsum forms part of the total amount of recycled gypsum reincorporated into the process (e.g. $5 \%$ by weight of new plasterboard in the 2013 base case).

\subsection{Primary energy and GHG emissions}

Based on these system-wide material flows, we apply energy and GHG intensity factors to each process to estimate overall energy use and GHG emissions. Primary energy and GHG emission intensity factors for gypsum mining, paper and additives manufacture are based on Ecoinvent (2012). For the case of plasterboard waste processing, gypsum pre-processing, demolition or deconstruction works and final disposal, data from Doka (2003), Plimmer et al (2007) and WRAP and Environmental Resources Management Ltd (ERM) (2008) have been used, as detailed in Table S2 in the Supplementary Data. Energy and emission intensity factors for deconstruction and waste segregation are used for recycled plasterboard, whereas factors for demolition are used for landfilled plasterboard. The ELCD process data set, together with an Explanatory note (Eurogypsum, 2010), are the main references for obtaining the energy and GHG emissions of the plasterboard manufacturing process. We assume that gypsum calcining and plasterboard production processes do not change with increased proportion of recycled gypsum, and only the preprocessing stage, which refers to the size reduction (crushing and grinding) and drying of the gypsum 
feedstock before calcination, varies in the different scenarios (WRAP and Environmental Resources Management Ltd (ERM), 2008).

397 Energy and emissions intensity factors for train, truck and ship transport are based on data published by the International Energy Agency for the year 2005 and the European Environment Agency for the year 2011, which are the most recent data found (European Environment Agency, 2011; International Energy Agency, 2008). EU-27 average electricity emissions factor, published by the European Environment Agency, has been utilized in this investigation (European Environment Agency (EEA), 2008). GHG emissions are quantified as $\mathrm{CO}_{2}$ equivalents, using global warming potential (GWP) characterization factors over a 100year time horizon (IPCC, 2013).

For estimating the distances travelled by raw materials, plasterboard, gypsum waste and recycled gypsum, we make the assumptions detailed in Table 4, based on related European LCI references. For the case of natural and FGD gypsum, two transport alternatives are considered, using weighting factors to reflect their potential occurrence. For this purpose, Germany, France and the UK are considered as representative of the EU-27 (European Commission Joint Research Centre - European reference Life-Cycle Database, 2007). In Case A, most common situation in Europe, natural gypsum is locally sourced (87\%) and FGD gypsum is transported from a nearby coal power station (89\%). In all other instances, Case B applies, which involves raw materials being imported (i.e. natural gypsum transportation is assessed by assuming $87 \%$ case $\mathrm{A}$ and $13 \%$ case $\mathrm{B})$.

Table 4. Transport details. RG: recycled gypsum.

\begin{tabular}{|c|c|c|c|c|c|c|c|}
\hline \multirow{2}{*}{$\begin{array}{l}\text { Materials, } \\
\text { products and } \\
\text { waste }\end{array}$} & \multirow{2}{*}{ From } & \multirow{2}{*}{ To } & \multirow{2}{*}{ Mode } & \multirow{2}{*}{ Source } & \multirow{2}{*}{$\begin{array}{l}\text { Distance } \\
(\mathrm{km})\end{array}$} & \multicolumn{2}{|c|}{ Baseline } \\
\hline & & & & & & Mt/year & Mtkm \\
\hline \multirow{3}{*}{$\begin{array}{l}\text { Natural gypsum } \\
\text { - Case A } \\
\text { Natural gypsum - } \\
\text { Case B }\end{array}$} & Mine or quarry & Manufacturing plant & Road & $\begin{array}{l}\text { EPD System, } \\
2013\end{array}$ & 2.00 & 7.04 & 14.09 \\
\hline & Mine or quarry (imp) & Manufacturing plant & Road & WRAP, 2008 & 16.00 & 7.04 & 112.72 \\
\hline & Mine or quarry (imp) & Manufacturing plant & Ship & WRAP, 2008 & $2,730.00$ & 7.04 & $\begin{array}{r}19,232.6 \\
0\end{array}$ \\
\hline \multirow[t]{2}{*}{$\begin{array}{l}\text { FGD gypsum - } \\
\text { Case A }\end{array}$} & Coal power station & Manufacturing plant & Road & WRAP, 2008 & 54.00 & 3.02 & 163.13 \\
\hline & Coal power station & Manufacturing plant & Rail & WRAP, 2008 & 54.00 & 3.02 & 163.13 \\
\hline \multirow[t]{2}{*}{$\begin{array}{l}\text { FGD gypsum - } \\
\text { Case B }\end{array}$} & Coal power station (imp) & Manufacturing plant & Road & WRAP, 2008 & 2.00 & 3.02 & 6.04 \\
\hline & Coal power station (imp) & Manufacturing plant & Ship & WRAP, 2008 & $1,083.00$ & 3.02 & $3,271.66$ \\
\hline Facing paper & Paper production & Manufacturing plant & Road & $\begin{array}{l}\text { Average } \\
\text { from WRAP, } \\
2008\end{array}$ & 200.00 & 0.45 & 89.01 \\
\hline Additives & Additives production & Manufacturing plant & Road & $\begin{array}{l}\text { Considered } \\
\text { by authors }\end{array}$ & 200.00 & 0.15 & 29.19 \\
\hline Plasterboard & Manufacturing plant & Building site & Road & $\begin{array}{l}\text { Average LCI } \\
\text { references } \\
\text { Average }\end{array}$ & 189.64 & 10.73 & $2,035.72$ \\
\hline C\&D PB waste & Building site & Waste processing & Road & $\begin{array}{l}\text { DA1 Report, } \\
\text { GtoG }\end{array}$ & 150.00 & 0.12 & 18.09 \\
\hline $\begin{array}{l}\text { RG (post- } \\
\text { consumer) }\end{array}$ & Waste processing (ext) & Manufacturing plant & Road & $\begin{array}{l}\text { Average } \\
\text { DA1 Report, } \\
\text { GtoG }\end{array}$ & 12.50 & 0.11 & 1.40 \\
\hline $\begin{array}{l}\text { RG (pre- } \\
\text { consumer) }\end{array}$ & Waste processing (int) & Manufacturing plant & Road & $\begin{array}{l}\text { DA1 Report, } \\
\text { GtoG }\end{array}$ & 0.00 & 0.45 & 0.00 \\
\hline $\begin{array}{l}\text { Plasterboard } \\
\text { waste }\end{array}$ & Jobsite or Manuf. plant & Landfill & Road & WRAP, 2008 & 40.00 & 1.66 & 66.45 \\
\hline
\end{tabular}

For the final disposal stage, our accounting considers the transport and operational burdens associated with the disposal of plasterboard in landfills, as well as emissions from landfills. When paper is deposited in mixed-waste landfills, it can be degraded by anaerobic bacteria, producing $\mathrm{CH}_{4}$ and $\mathrm{CO}_{2}$. We model landfill 
emissions based on data from Plimmer et al. (2007), who used the GasSim2 tool developed for the UK Environmental Agency. In our life cycle model, we disregard the direct $\mathrm{CO}_{2}$ emission from lining paper degradation, as it is part of the natural carbon cycle of growth and decomposition (United States Environmental Protection Agency EPA, 2015). We assume that $75 \%$ percent of the $\mathrm{CH}_{4}$ produced from the decomposition of lining paper is recovered and flared to $\mathrm{CO}_{2}$. For simplicity, we do not consider the energy of the recovered gas and its potential conversion and use. The remaining $25 \%$ of produced $\mathrm{CH}_{4}$ is assumed to escape to the atmosphere (Plimmer et al. 2007). We convert this $\mathrm{CH}_{4}$ emission to equivalent $\mathrm{CO}_{2}$ emission using a global warming potential (GWP) of 34 , and include these emissions in our accounting. In a sensitivity analysis, we also consider landfilling in a monocell landfill with zero $\mathrm{CH}_{4}$ emissions, and in a mixed-waste landfill with only $50 \%$ recovery of $\mathrm{CH}_{4}$.

\section{Results and discussion: Implications of gypsum plasterboard recycling in the EU-27}

This section presents the mass flow, primary energy use and GHG emissions implications of the different recycling scenarios.

\subsection{Mass flow implications}

Fig. 2 shows the composition by weight percentage of the resulting three plasterboards in the considered scenarios: zero recycling case, 2013 base case and high recycling case. In our model, the natural gypsum used depends on the recycled gypsum content, whereas the FGD gypsum, paper and additives remain fixed in the 3 scenarios. In all cases, natural gypsum dominates the material mass, followed by the FGD gypsum. Recycled gypsum comprises $0.0 \%$ of the zero recycling case, $5 \%$ of the 2013 base case and $18.7 \%$ of the high recycling case plasterboard.
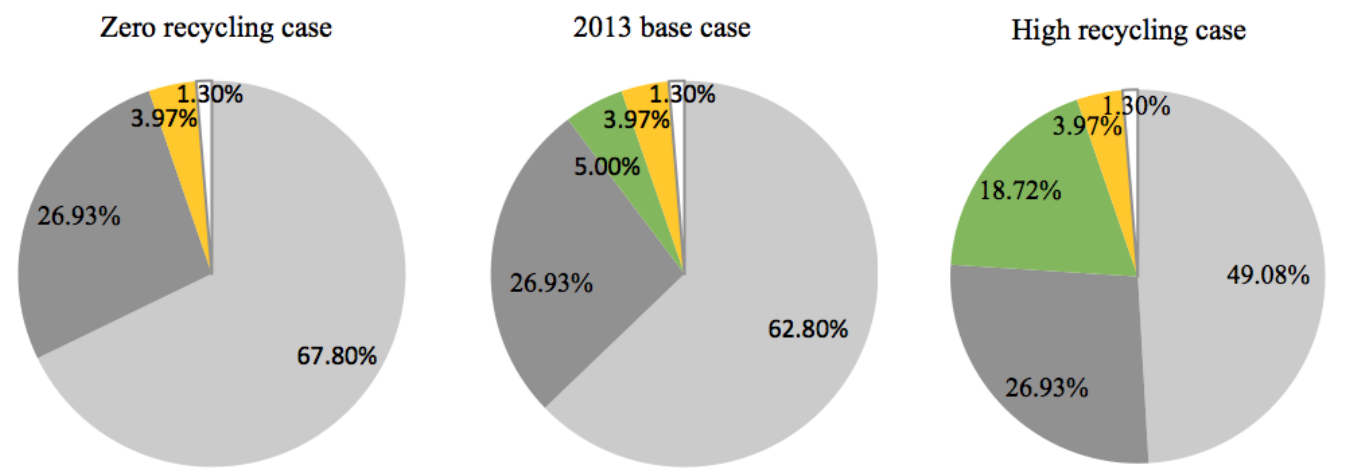

Natural gypsum

- FGD gypsum

- Recycled gypsum

- Paper

$\square$ Additives

Fig. 2. Composition, by weight percentage, of the two plasterboard compositions derived from the alternative scenarios (left and right) and the Reference plasterboard (2013 base case)

The system-wide mass flows in the different scenarios allow us to determine the fate of post-consumer plasterboard waste. In the zero recycling case, $93.6 \%$ is landfilled and $6.4 \%$ is used for other uses. In the 2013 base case, $87.2 \%$ is landfilled, $6.4 \%$ is used for other uses, and $6.4 \%$ is recycled into plasterboard (closed-loop recycling). This corresponds to $5.0 \%$ recycled gypsum content in new plasterboard production. In the high recycling case, $0.0 \%$ is landfilled, $6.4 \%$ is used for other uses, and $93.6 \%$ is recycled into plasterboard (closed-loop recycling), corresponding to a $18.7 \%$ recycled content in new plasterboard.

The plasterboard raw gypsum source and post-consumer plasterboard waste fate in the 3 different scenarios is shown in Fig. 3. It should be noted that, based on the mass balance equations, the amount of FGD gypsum incorporated equals 3.02 Mt/year, which is less than the 5.17 Mt in 2010 (ECOBA - European Coal Combustion Products Association, 2010). We assume that this difference may be due to the manufacturing of other non-faced plaster products, outside the scope of this analysis. 


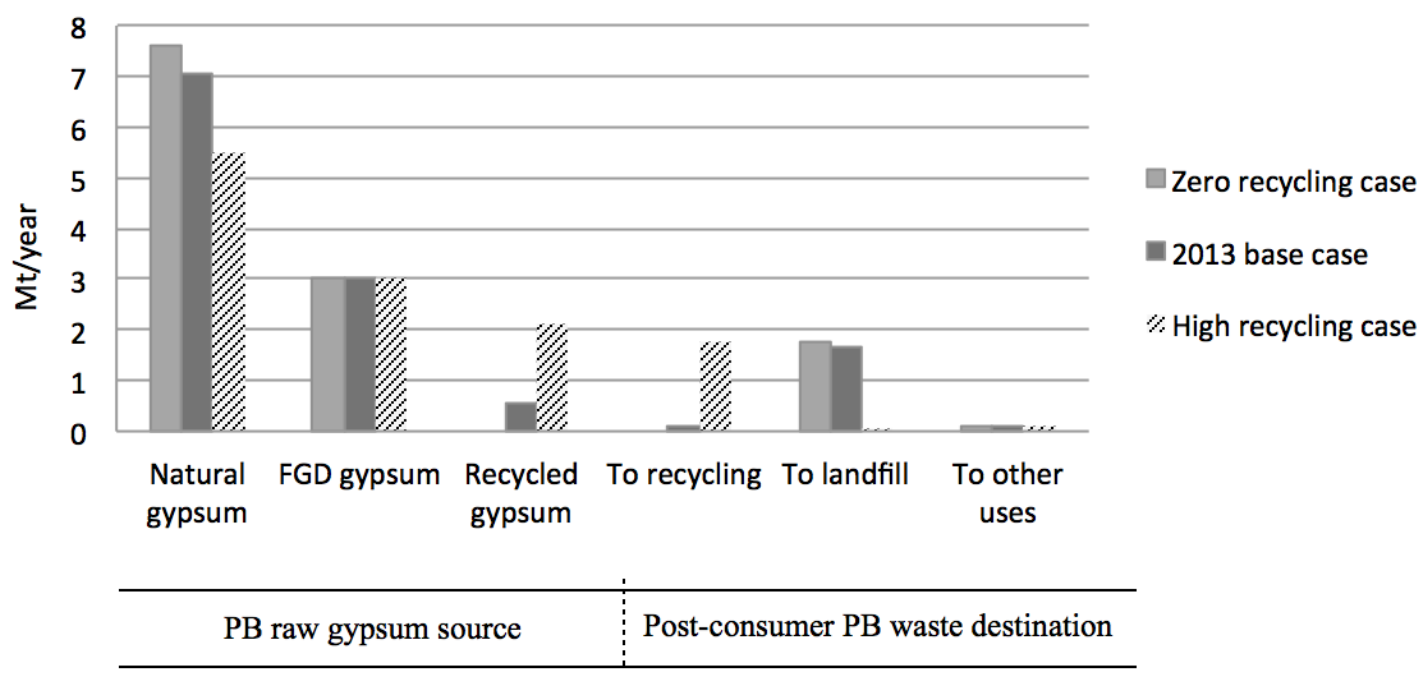

Fig. 3. Raw material and waste in the 3 different scenarios, in million tonnes per year (Mt/year). PB=plasterboard

In the high recycling case, $1.65 \mathrm{Mt} / \mathrm{year}$ of plasterboard waste landfilling is avoided, compared to the 2013 base case. This significant reduction in plasterboard landfilling would contribute to mitigating primary resource depletion and preventing $\mathrm{H}_{2} \mathrm{~S}$ and $\mathrm{CH}_{4}$ emissions from landfills.

\subsection{Primary energy implications}

Fig. 4 and Fig. 5 show the impact, in terms of primary energy use, of increased gypsum recycling in new plasterboard production in the three scenarios. The functional unit (FU) is one square meter of plasterboard consumed.

The highest primary energy use results from reincorporating $18.7 \%$ of recycled gypsum (high recycling case), although the energy difference between this value and the other two scenarios is very small: 43.09 $\mathrm{MJ} / \mathrm{m}^{2}$ in the zero recycling case and 2013 base case and $43.62 \mathrm{MJ} / \mathrm{m}^{2}$ in the high recycling case. Increased recycling leads to decreased energy use in gypsum mining, transport of natural gypsum to the manufacturing plant and transport of plasterboard waste to landfill. However, it increases the transport of plasterboard waste to the recycling facility, the energy use for waste processing, the transport of the recycled gypsum to the manufacturing plant and the energy use for gypsum pre-processing.

The plasterboard manufacturing process constitutes around $46 \%$ of the plasterboard life cycle's primary energy use $\left(19.75 \mathrm{MJ} / \mathrm{m}^{2}\right.$ in the 2013 base case). Variations with increased recycled content are very low: $1 \%$ increased energy use with a shift from the 2013 base to the high recycling case, mainly explained by the higher pre-processing energy demand.

Transport of raw materials is responsible for a substantial portion of total energy use. The impacts of transporting natural gypsum in the zero recycling case are reduced by $38 \%$ in the high recycling case. The transport of post-consumer plasterboard waste to processing varies from $0.05 \mathrm{MJ} / \mathrm{m}^{2}$ in 2013 base case to $0.68 \mathrm{MJ} / \mathrm{m}^{2}$ in the high recycling case. However, it is largely offset by primary energy decrease for postconsumer plasterboard waste transported to landfill disposal, from $0.17 \mathrm{MJ} / \mathrm{m}^{2}$ (2013 base case) to zero (high recycling case). 


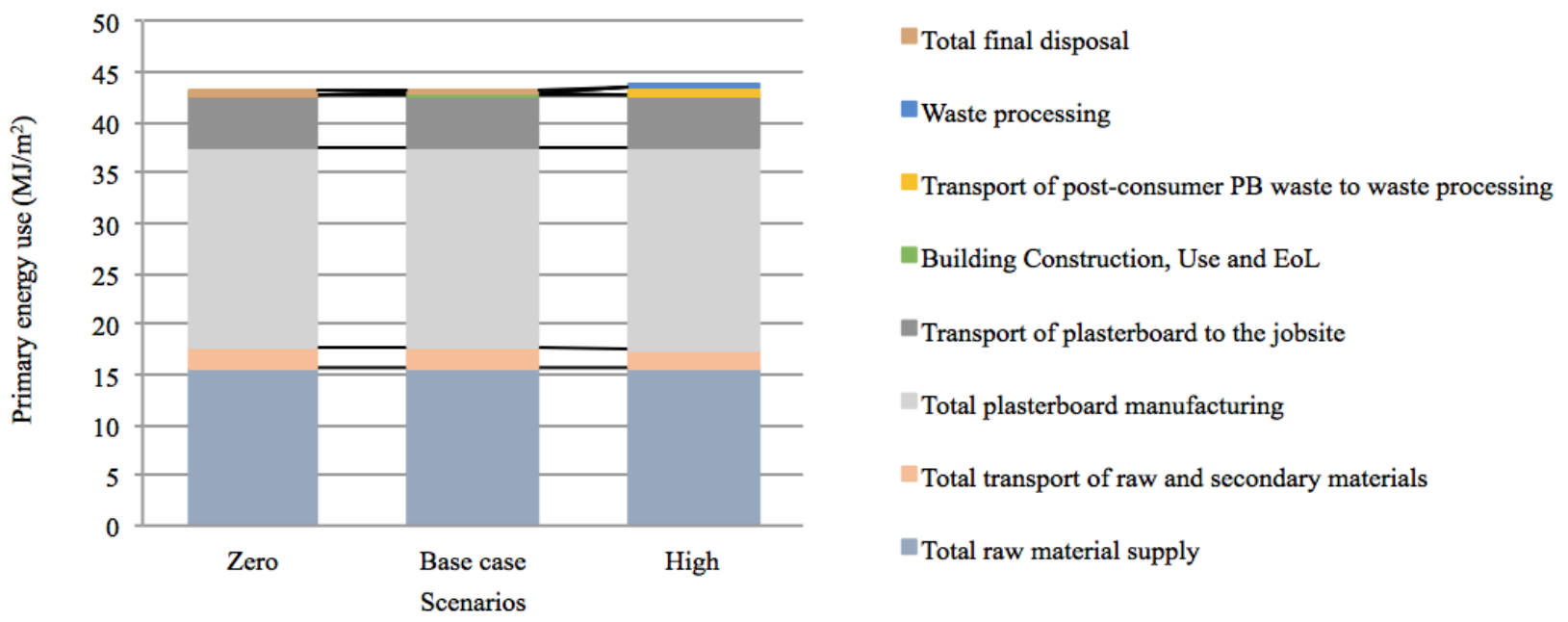

Fig. 4. Primary energy use per square meter of plasterboard consumed.

There are no savings on the total energy use when moving from the 2013 base case towards the high recycling case. Overall, $568.34 \mathrm{TJ}$ increase of primary energy per year result as a consequence of increases in transport of post-consumer plasterboard waste to the recycling facility and transport of recycled gypsum to the manufacturing plant.

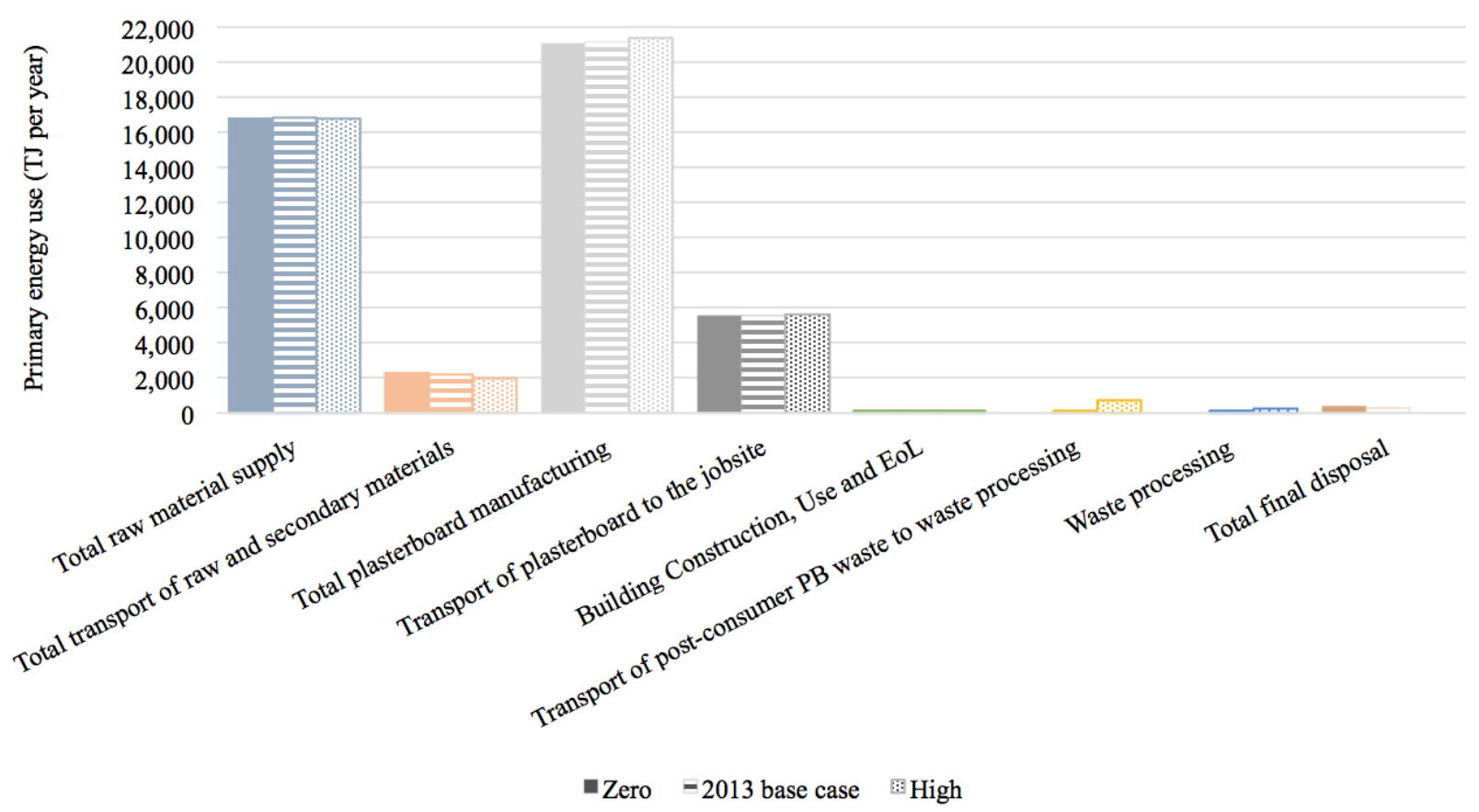

Fig. 5. Primary energy use in TJ per year within the EU-27 plasterboard life cycle.

\subsection{GHG emissions implications}

The potential contribution of different plasterboard recycling scenarios to the global warming impact category, expressed as $\mathrm{CO}_{2}$ equivalents, is estimated by quantifying all significant GHG emissions and removals over the product's life cycle (International Standard, 2013) in the three scenarios, as Fig. 6 and Fig. 7 present.

GHG emitted from raw material supply to plasterboard production stages (modules A1 - A3 according to EN 15804) equals $2.05 \mathrm{~kg} \mathrm{CO}_{2}$ eq in the 2013 base case, and $2.06 \mathrm{~kg} \mathrm{CO}_{2}$ eq in the high recycling case, per 
square meter of plasterboard. This minor difference means that decreased emissions derived from gypsum mining and transport of natural gypsum in the high recycling case are almost balanced by the increased emissions from the pre-processing stage. The variations of the cradle-to-cradle lifecycle emissions are higher when moving from the 2013 base case $\left(2.45 \mathrm{~kg} \mathrm{CO}\right.$ eq/m $\left.{ }^{2}\right)$ towards the high recycling case $\left(2.23 \mathrm{~kg} \mathrm{CO}_{2}\right.$ $\mathrm{eq} / \mathrm{m}^{2}$ ). Overall, the total GHG emission is $9 \%$ smaller in the high recycling case. GHG emissions are slightly greater in the processes of transport of recycled gypsum, pre-processing stage, transport of plasterboard waste to recycling and waste processing. Such emissions are lower for gypsum mining, transport of natural gypsum and final disposal. The latter emissions from landfill have a decisive contribution to the final result, due to methane released from degradation of facing paper. This biogenic emission constitutes $94 \%$ of the emissions in the final disposal stage and $10 \%$ of the total life cycle emissions.
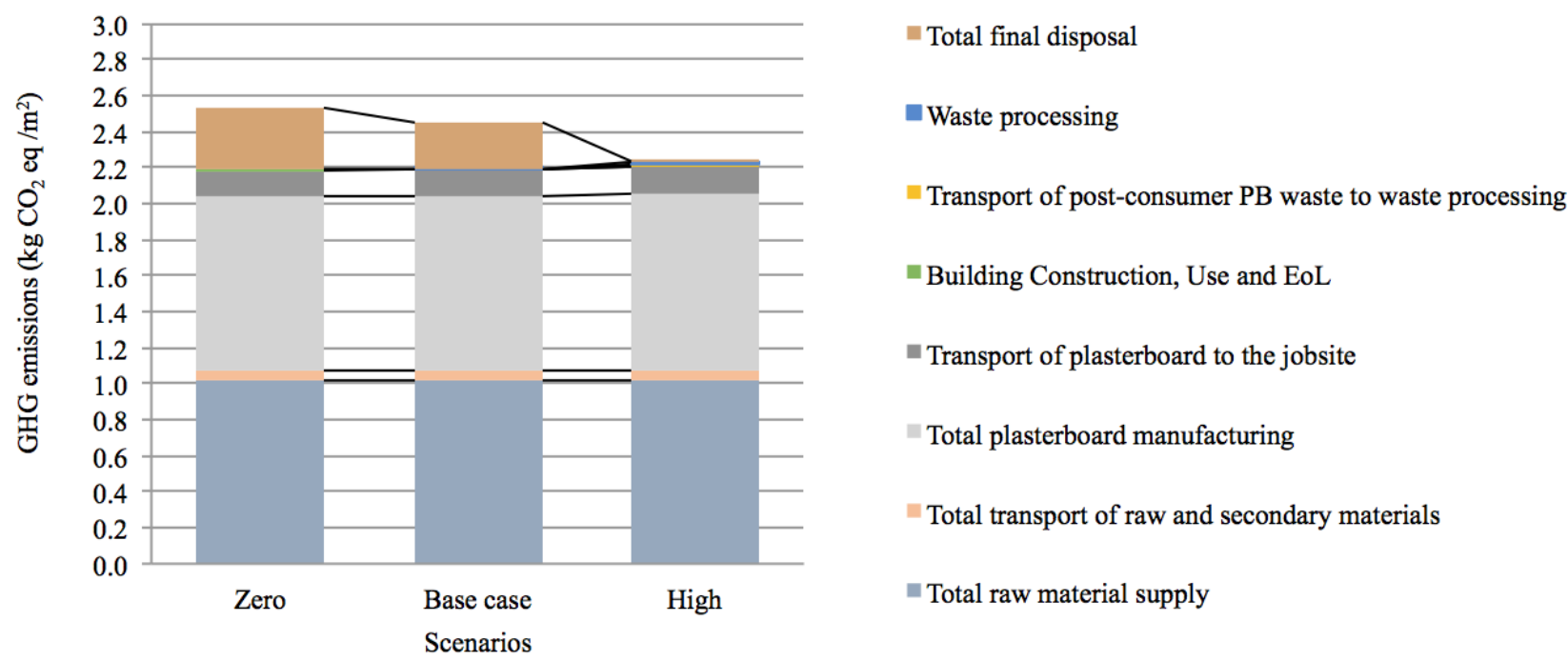

Fig. 6. GHG emissions per square meter of plasterboard consumed.

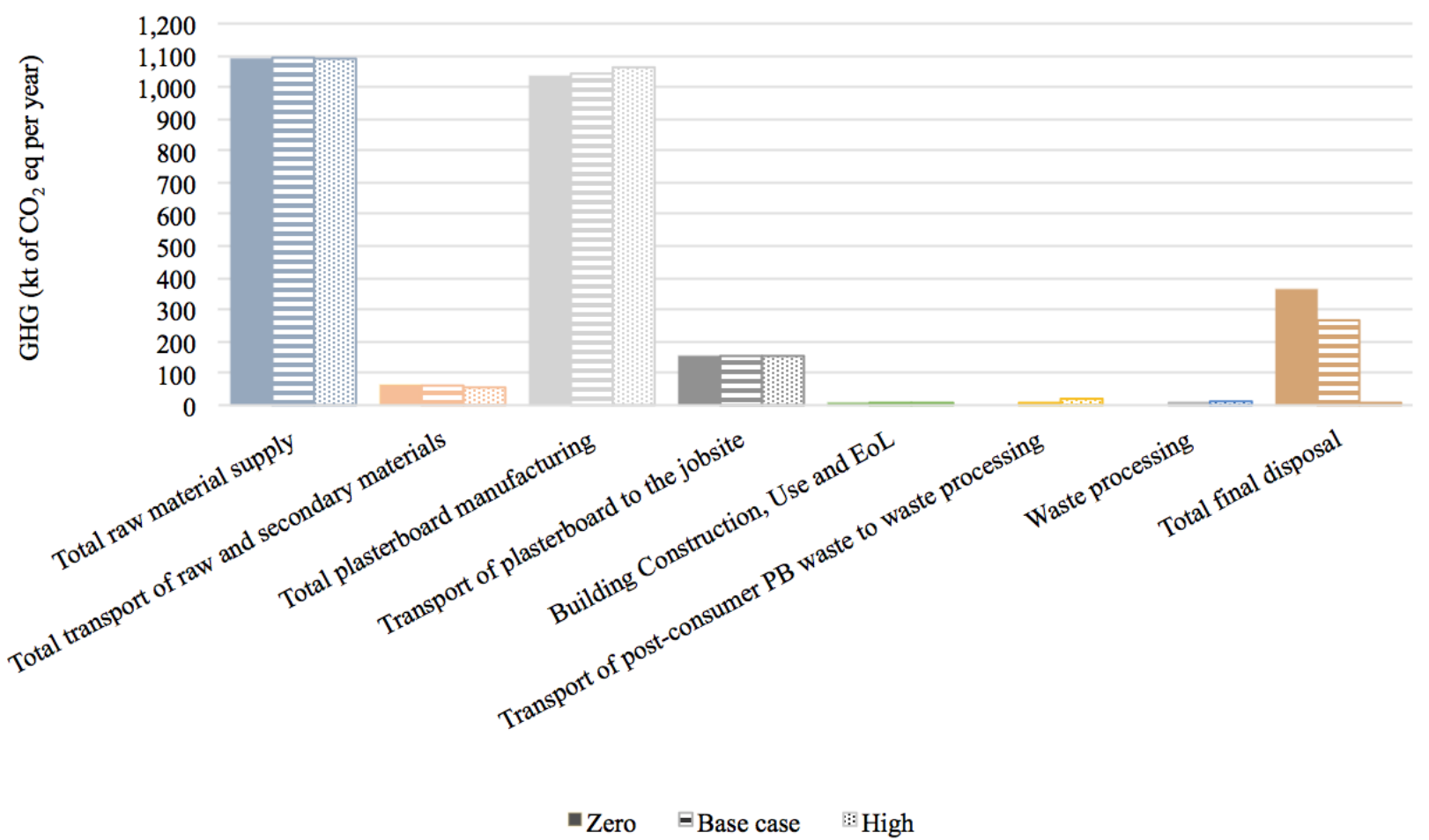

Fig. 7 GHG emissions, in kt of $\mathrm{CO}_{2}$ eq per year, of the EU-27 plasterboard life cycle. 
Here we explore the effect of variation of input parameters on the two metrics previously modelled: primary energy use $\left(\mathrm{MJ} / \mathrm{m}^{2}\right)$ and $\mathrm{GHG}$ emissions $\left(\mathrm{kg} \mathrm{CO}_{2} \mathrm{eq} / \mathrm{m}^{2}\right)$. Table 6 summarizes the results of the sensitivity analysis performed on three criteria: $\mathrm{C} \& \mathrm{D}$ waste generated, transport and plasterboard final disposal.

Table 6. Effect of varying parameters in the primary energy use and GHG emissions over the life cycle of plasterboard. Ref: reference. PB: plasterboard. Values in the columns termed as "Base case" correspond to the 2013 base case results.

\begin{tabular}{|c|c|c|c|c|c|c|}
\hline \multirow[b]{2}{*}{ Parameter } & \multirow{2}{*}{$\begin{array}{l}\text { Reference } \\
\text { condition }\end{array}$} & \multirow{2}{*}{$\begin{array}{l}\text { New } \\
\text { condition }\end{array}$} & \multicolumn{2}{|c|}{$\mathrm{PE}\left(\mathrm{MJ} / \mathrm{m}^{2}\right)$} & \multicolumn{2}{|c|}{$\mathrm{GHG}\left(\mathrm{kg} \mathrm{CO} \mathrm{CO}_{2} \mathrm{eq} \mathrm{m}^{2}\right)$} \\
\hline & & & $\begin{array}{l}\text { Base } \\
\text { case }\end{array}$ & $\begin{array}{l}\text { Change from } \\
\text { ref }\end{array}$ & $\begin{array}{l}\text { Base } \\
\text { case }\end{array}$ & $\begin{array}{l}\text { Change from } \\
\text { ref }\end{array}$ \\
\hline \multicolumn{7}{|l|}{$C \& D$ waste generation } \\
\hline Post-consumer plasterboard waste (Mt) & 1.90 & $-20 \%$ & 43.02 & -0.07 & 2.39 & -0.06 \\
\hline Post-consumer plasterboard waste (Mt) & 1.90 & $+20 \%$ & 43.16 & 0.07 & 2.50 & 0.06 \\
\hline \multicolumn{7}{|l|}{ Transport } \\
\hline Natural gypsum, weighting factor case A (\%) & 0.87 & 0.97 & 42.23 & -0.86 & 2.43 & -0.02 \\
\hline Plasterboard to building site (km) & 189.64 & $-20 \%$ & 42.05 & -1.04 & 2.42 & -0.03 \\
\hline Plasterboard to building site $(\mathrm{km})$ & 189.64 & $+20 \%$ & 44.12 & 1.04 & 2.48 & 0.03 \\
\hline \multicolumn{7}{|l|}{ Final disposal } \\
\hline Collection efficiency of landfill gas (\%) & 0.75 & 0.50 & 43.09 & 0.00 & 2.67 & 0.22 \\
\hline $\begin{array}{l}\text { Disposal in monocell landfill }-\mathrm{CH}_{4}(\mathrm{~kg} / \mathrm{t} \mathrm{PB} \\
\text { deposited) }\end{array}$ & 4.48 & 0.00 & 43.09 & 0.00 & 2.21 & -0.24 \\
\hline
\end{tabular}

522

Only those parameters that exceed an effect of $1 \%$ change on the life cycle of plasterboard are included in the sensitivity results. Generally, the sensitivity variation is symmetric, varying uniformly in the positive and negative direction. The GHG emissions derived from final disposal vary by $2 \%$ as the post-consumer plasterboard waste generated changes from 1.90 to 1.52 and $2.28 \mathrm{Mt}$. Increase of the case A natural gypsum weighting factor by $10 \%$ results in $2 \%$ reduction in total primary energy and $1 \%$ reduction in GHG emissions. Variation of the transport to building site to $152 \mathrm{~km}$ reduces the primary energy demand and GHG emissions by 2 and $1 \%$ respectively. Landfill gas collection efficiencies have been typically estimated to be in the range of 50-75\% (Spokas et al., 2006). Reduction of the assumed collection efficiency of landfill gas from $75 \%$ down to $50 \%$, increases the total biogenic emissions released by $9 \%$ compared to the reference scenario. In addition, if plasterboard is deposited in a monocell landfill instead of a mixed-waste landfill, the $\mathrm{CH}_{4}$ emissions associated with paper degradation are assumed to be zero, as the amount of methane produced in monocells is small and released at a low rate, thus undergoing oxidation to carbon dioxide in the surface layers of the site before it could be released into the atmosphere (WRAP and Environmental Resources Management Ltd (ERM), 2008). This change in the type of disposal results in a $10 \%$ decrease of total GHG emissions. Thus, $\mathrm{CH}_{4}$ emissions coming from paper content degradation make a significant difference in the total GHG emissions, as a function of the landfill type and gas recovery infrastructure.

\section{Conclusions}

This paper presents quantitative scenario modelling of gypsum plasterboard recycling in the EU-27. A life cycle model is the basis of the assessment, from which the known mass flows are quantified, using principles of mass balance to determine flows of other materials, e.g. facing paper or post-consumer plasterboard waste. Based on these system-wide mass flows, we apply energy and GHG intensity factors to each process to estimate total life cycle energy use and GHG emissions. 
Representative scenarios are defined ("Zero recycling case", "2013 base case", "High recycling case") and different assumptions based on LCI references (e.g. transport distances travelled) are considered, with the aim of evaluating the impact of different levels of recycled gypsum reincorporated in the manufacturing process $(0 \%, 5 \%, 18.7 \%$, respectively).

The main conclusions that can be drawn from this investigation are:

- The composition by weight percentage of the resulting three plasterboards show that natural gypsum comprises around $68 \%$ in the zero recycling case, decreasing to $63 \%$ in the 2013 base case and $49 \%$ in the high recycling case.

- In the 2013 base case, 5\% recycled gypsum content in new plasterboard corresponds to $6.4 \%$ plasterboard waste recycled into plasterboard (closed-loop recycling). In the zero recycling case, all plasterboard waste is either landfilled (93.6\%) or utilised for other uses $(6.4 \%)$. In the high recycling case, $18.7 \%$ of recycled gypsum is reincorporated, corresponding to $93.6 \%$ closed-loop plasterboard recycling.

- When moving from the 2013 base case to the high recycling case, $1.65 \mathrm{Mt} / \mathrm{year}$ of plasterboard waste landfilling is avoided, therefore contributing to mitigating primary resource depletion and preventing $\mathrm{H}_{2} \mathrm{~S}$ and $\mathrm{CH}_{4}$ emissions from landfills.

- Reincorporating greater amounts of recycled gypsum results in higher overall primary energy use. However, the difference between the scenarios is very minor: $43.09 \mathrm{MJ} / \mathrm{m}^{2}$ in the zero recycling and 2013 base cases and $43.62 \mathrm{MJ} / \mathrm{m}^{2}$ in the high recycling case.

- The potential contribution of different plasterboard scenarios to global warming, expressed as $\mathrm{CO}_{2}$ equivalents, result in greater differences: $2.53 \mathrm{~kg} \mathrm{CO}$ eq $/ \mathrm{m}^{2}$ in the zero recycling case, $2.45 \mathrm{~kg} \mathrm{CO}$ $\mathrm{eq} / \mathrm{m}^{2}$ in the 2013 base case and $2.23 \mathrm{~kg} \mathrm{CO}_{2} \mathrm{eq} / \mathrm{m}^{2}$ in the high recycling case. Biogenic emissions from paper degradation in the end-of-life stage, which are dependent on landfill type and infrastructure, are primary drivers of the difference between total GHG emissions in the different scenarios.

- For both primary energy use and GHG emissions, when moving from the zero recycling case towards the high recycling case, greater impacts occur in the processes of transport of recycled gypsum, preprocessing stage, transport of plasterboard waste to recycling and waste processing, while lower impacts are observed in gypsum mining, transport of natural gypsum and final disposal.

- The representative scenarios incorporate assumptions in an attempt to communicate relevant results for the EU average plasterboard. For plasterboards with parameters that deviate from this average, different results may apply.

\section{Acknowledgement}

This study has been performed under the framework of the GtoG project, supported by the European Commission - DG Environment through the Life + programme; under contract number LIFE11 ENV/BE/001039. Lawrence Berkeley National Laboratory is supported by the US Department of Energy under Contract No. DE-AC02-05CH11231.

\section{Appendix A. Supplementary data}

Supplementary data related to this article can be found at (doi) 


\section{References}

Antink, R., Garrigan, C., Bonetti, M., \& Westaway, R. (2014). Greening the Building Supply Chain. UNEP Sustainable Buildings and Climate Initiative. United Nations Environment Programme. Job Number: DTI/1753/PA. Retrieved January 17, 2016, from http://www.unep.org/sbci/pdfs/greening_the_supply_chain_report.pdf

Bojić, M., Djordjević, S., Stefanović, A., Miletić, M., \& Cvetković, D. (2012). Decreasing energy consumption in thermally non-insulated old house via refurbishment. Energy and Buildings, 54, 503510. doi:10.1016/j.enbuild.2012.03.045

Construction Recycling Initiative (CRI) - National Capital Region. (2010). GYPSUM Recycling in the National Capital Region. Position Paper.

Dodoo, A., Gustavsson, L., \& Sathre, R. (2010). Life cycle primary energy implication of retrofitting a wood-framed apartment building to passive house standard. Resources, Conservation and Recycling, 54(12), 1152-1160. doi:10.1016/j.resconrec.2010.03.010

Doka, G. (2003). Life Cycle Inventories of Waste Treatment Services. ecoinvent report No. 13. Part V. Building Material Disposal. Final report of the project of a National Life Cycle Inventory Database "ecoinvent 2000" commissioned by BUWAL/BFE/ASTRA/BLW. Dübendorf.

ECOBA - European Coal Combustion Products Association. (2010). Production and Utilisation of CCPs in 2010 in Europe (EU 15). Retrieved January 17, 2016, from http://www.ecoba.com/ecobaccpprod.html

Ecoinvent. (2012). Ecoinvent v2.2 Life Cycle Inventory (LCI) database, Gypsum, mineral, at mine/CH S.

Emery, S. B., Smith, D. N., Gaterell, M. R., Sammons, G., \& Moon, D. (2007). Estimation of the recycled content of an existing construction project. Resources, Conservation and Recycling, 52(2), 395-409. doi:10.1016/j.resconrec.2007.03.009

EPA's Waste Reduction Model (WARM). (2014). WARM Version 13 - Drywall.

Eurogypsum. (2010). European Life Cycle Assessment on Plasterboard: European Environmental Declaration - Explanatory Note.

European Commission. (2011). Service Contract on Management of Construction and Demolition Waste SR1. Retrieved January 17, 2016, from http://ec.europa.eu/environment/waste/pdf/2011_CDW_Report.pdf

European Commission. Communication from the Commission to the European Parliament, the Council, the European Economic and Social Committee and the Committee of the Regions. Towards a circular economy: A zero waste programme for Europe (2014).

European Commission. Proposal for a Directive of the European Parliamente and the Council (2014).

European Commission DG Environment. (2010). Green Public Procurement Wall Panels Technical Background Report.

European Commission Joint Research Centre - European reference Life-Cycle Database. (2007). Process data set: Gypsum plasterboard (03.00.000). Gypsum plasterboard;technology mix of plasterboard production;production mix at factory; $12.5 \mathrm{~mm}$ thick, $10 \mathrm{~kg} / \mathrm{m} 2$. Retrieved January 17,2016 , from http://eplca.jrc.ec.europa.eu/ELCD3/showProcess.xhtml;jsessionid=2703835E85D137D1E5882A56E8 BBD0C6?uuid=cc39e 70e-4a40-42b6-89e3-7305f0b95dc4\&version=03.00.000

European Environment Agency. (2011). Specific CO2 emissions per tonne-km and per mode of transport in Europe, 1995-2011 - European Environment Agency (EEA). Retrieved January 17, 2016, from http://www.eea.europa.eu/data-and-maps/figures/specific-co2-emissions-per-tonne-2

European Environment Agency (EEA). (2008). Trends in energy GHG emission factors and \% renewable electricity (EU-27). Retrieved January 17, 2016, from http://www.eea.europa.eu/data-andmaps/figures/trends-in-energy-ghg-emission 
Eurostat. (2012). Generation of waste, NACE_R2: Construction.

Eurostat - Prodcom. (2013a). NACE Rev. 2. Statistics on the production of manufactured goods, total volume annual 2013.

Eurostat - Prodcom. (2013b). PRODCOM ANNUAL TOTAL (NACE Rev.2). PRCCODE: 08112030.

Govindan, K., Soleimani, H., \& Kannan, D. (2014). Reverse logistics and closed-loop supply chain: A comprehensive review to explore the future. European Journal of Operational Research, 240(3), 603626. doi:10.1016/j.ejor.2014.07.012

GtoG Project. (2013). GtoG LIFE 11 ENV/BE/001039. Retrieved January 17, 2016, from http://ec.europa.eu/environment/life/project/Projects/index.cfm?fuseaction=search.dspPage\&n_proj_id $=4191$

Gypsum to Gypsum project LIFE11 ENV/BE/001039. (2013). DA1: Inventory of current practices. Retrieved January 17, 2016, from http://gypsumtogypsum.org/documents/deliverable-a1-report-oncurrent-practices.pdf

Gypsum to Gypsum project LIFE11 ENV/BE/001039. (2015). DC1. Report on best practice indicators for deconstruction, recycling and reincorporation. Retrieved January 17, 2016, from http://ec.europa.eu/environment/life/news/newsarchive2015/documents/20150715_gtog.pdf

Herrero, M. J., Escavy, J. I., \& Bustillo, M. (2013). The Spanish building crisis and its effect in the gypsum quarry production (1998-2012). Resources Policy, 38(2), 123-129. doi:10.1016/j.resourpol.2013.02.005

International Energy Agency. (2008). Worldwide Trends in Energy Use and Efficiency INDICATORS. Key Insights from IEA Indicator Analysis. IEA Publications.

International Standard. (1999). ISO 14021:1999/Amd 1:2011. Environmental labels and declarations - Selfdeclared environmental claims (Type II environmental labelling). Amendment 1.

International Standard. ISO 14040:2006. Environmental management - Life cycle assessment - Principles and framework (2006).

International Standard. ISO 14044:2006. Environmental management - Life cycle assessment - Requirements and guidelines (2006).

International Standard. (2013). ISO/TS 14067:2013. Greenhouse gases -- Carbon footprint of products -Requirements and guidelines for quantification and communication.

IPCC. (2013). Fifth Assessment Report - Climate Change. Retrieved from http://www.ipcc.ch/report/ar5/wg1/

Kourmpanis, B., Papadopoulos, a., Moustakas, K., Stylianou, M., Haralambous, K. J., \& Loizidou, M. (2008). Preliminary study for the management of construction and demolition waste. Waste Management \& Research, 26(3), 267-275. doi:10.1177/0734242X07083344

OSHA Occupational Safety and Health Administration. US Department of Labor. (2005). Hydrogen Sulfide OSHA FactSheet. DSG 10/2005. Retrieved January 17, 2016, from https://www.osha.gov/OshDoc/data_Hurricane_Facts/hydrogen_sulfide_fact.pdf

Plimmer, B., Davies, S., \& Carter, L. (2007). Report on Life Cycle Assessment of Plasterboard PBD014, Landfill Emissions Inventory 07514290064.500.

Roskill. (2014). Gypsum and Anhydrite: Global Industry Markets and Outlook.

Spokas, K., Bogner, J., Chanton, J. P., Morcet, M., Aran, C., Graff, C., ... Hebe, I. (2006). Methane mass balance at three landfill sites: What is the efficiency of capture by gas collection systems? Waste Management, 26(5), 516-525. doi:10.1016/j.wasman.2005.07.021

Tam, V. W. Y., Fung, I. W. H., Sing, M. C. P., \& Ogunlana, S. O. (2014). Best practice of prefabrication implementation in the Hong Kong public and private sectors. Journal of Cleaner Production. 
doi:10.1016/j.jclepro.2014.09.045

680

681 682

683 684
The Council of the European Union. (2003). Council Decision of 19 December 2002 establishing criteria and procedures for the acceptance of waste at landfills pursuant to Article 16 of and Annex to Directive 1999/31/EC (2003/33/EC). Official Journal of the European Communities, L 11/27.

U.S. Geological Survey - USGS. (2013). Minerals Information - Gypsum Statistics and Information. Retrieved January 17, 2015, from http://minerals.usgs.gov/minerals/pubs/commodity/gypsum/

United States Environmental Protection Agency EPA. (2015). Landfilling. Retrieved January 17, 2016, from http://www3.epa.gov/epawaste/conserve/tools/warm/pdfs/Landfilling.pdf

Venta, G. J. (1997). Life cycle analysis of gypsum board and associated finishing products.

Villoria Sáez, P., del Río Merino, M., Porras-Amores, C., \& San-Antonio González, A. (2014). Assessing the accumulation of construction waste generation during residential building construction works. Resources, Conservation and Recycling, 93, 67-74. doi:10.1016/j.resconrec.2014.10.004

Williams, B. (2008). Europroms PRODCOM Data, User Guide, 1-18.

WRAP and Environmental Resources Management Ltd (ERM). (2008). WRAP Technical Report: Life Cycle Assessment of Plasterboard.

WRAP, \& BSI. (2013). PAS 109:2013. Specification for the production of reprocessed gypsum from waste plasterboard.

Xu, Q., \& Townsend, T. (2014). Factors affecting temporal H2S emission at construction and demolition (C\&D) debris landfills. Chemosphere, 96, 105-11. doi:10.1016/j.chemosphere.2013.07.052 